\title{
Mechanisms shaping the role of ERK1/2 in cellular senescence (Review)
}

\author{
JUNRONG ZOU ${ }^{1,2^{*}}$, TINGTING LEI ${ }^{1,2^{*}}$, PEI GUO ${ }^{3}$, JASON YU $^{4}$, QICHAO XU $^{5}$, \\ YUNFEI LUO ${ }^{2}$, RONG KE $^{6}$ and DEQIANG HUANG ${ }^{1}$
}

\footnotetext{
${ }^{1}$ Research Institute of Digestive Diseases, Department of Gastroenterology, The First Affiliated Hospital of Nanchang University;

${ }^{2}$ Jiangxi Provincial Key Laboratory of Tumor Pathogenesis and Molecular Pathology, Department of Pathophysiology, School of Basic Medical Sciences, Medical College of Nanchang University, Nanchang, Jiangxi 330006;

${ }^{3}$ Department of Pathology, Shenzhen Hospital of Southern Medical University, Shenzhen, Guangdong 518110,

P.R. China; ${ }^{4}$ Department of Pharmacology, Boston University School of Medicine, Boston, MA 02118, USA;

${ }^{5}$ Department of Pharmacology, The People's Hospital of Xinyu City, Xinyu, Jiangxi 338025, P.R. China;

${ }^{6}$ Department of Surgery, University of Illinois at Chicago College of Medicine, Chicago, IL 60612, USA
}

Received May 21, 2018; Accepted October 10, 2018

DOI: $10.3892 / \mathrm{mmr} .2018 .9712$

\begin{abstract}
Senescence is a result of cellular stress and is a potential mechanism for regulating cancer. As a member of the mitogen-activated protein kinase family, ERK1/2 (extracellular signal-regulated protein kinase) has an important role in delivering extracellular signals to the nucleus, and these signals regulate the cell cycle, cell proliferation and cell development. Previous studies demonstrated that ERK1/2 is closely associated with cell aging; however other previous studies suggested that ERK1/2 exerts an opposite effect on aging models and target proteins, even within the same cell model. Recent studies demonstrated that the effect of ERK1/2 on aging is likely associated with its target proteins and regulators, negative feedback loops, phosphorylated ERK1/2 factors and ERK1/2 translocation from the cytoplasm to the nucleus. The present review aims to examine the mechanism of ERK1/2 and discuss its role in cellular outcomes and novel drug development.
\end{abstract}

\section{Contents}

1. Introduction

2. Senescence, ERK1/2 and cell fate

Correspondence to: Dr Deqiang Huang, Research Institute of Digestive Diseases, Department of Gastroenterology, The First Affiliated Hospital of Nanchang University, 17 Yongwai Main Street, Nanchang, Jiangxi 330006, P.R. China

E-mail: hdq0515@163.com

*Contributed equally

Key words: extracellular signal-regulated protein kinase 1/2, senescence, dual role, feedback, translocation
3. ERK $1 / 2$ promotes cellular proliferation

4. ERK1/2 promotes cellular senescence through several mechanisms

5. Conclusion

\section{Introduction}

The Hayflick limit is a response to cellular lesions, which are triggered by multiple mechanisms, including replicative senescence, oncogene activation, telomerase dysfunction and DNA lesions (1-3). Senescent cells arrested at the $\mathrm{G}_{1}$ phase demonstrated more properties associated with dysfunctional cells compared with normal cells (4). Although senescence is an undesirable stress for normal cells, it is beneficial for the body as it restrains excessive proliferation of tumor cells. Therefore, senescence is used as a means of suppressing cancer and is an important cancer treatment method (5-8).

Extracellular signal-regulated protein kinase (ERK) $1 / 2$ is a mitogen-activated protein kinase (MAPK) family protein with typical cascade signaling characteristics and serves an important role in signal transduction pathways and the function of transcription factors, including activator protein-1, proto-oncogene c-Fos (c-Fos) and ETS domain-containing protein Elk-1 (Elk1) (9). The majority of research has focused on its regulatory effect on cell growth and differentiation (10-14); however, a number of previous studies demonstrated that ERK1/2 promotes cell senescence (15-17). Based on these characteristics, numerous small molecule MAPK/ERK kinase (MEK) inhibitors were examined in early-phase clinical trials, including PD098059, U0126, CI-1040, PD0325901 and AZD6244 (18); however, none of them were approved by The Food and Drug Administration due to adverse side effects or other toxic reactions (18). Many of these inhibitors negatively affected normal and abnormal cells. Notably, these effects may have been the result of the dual roles of ERK1/2 in senescence, as demonstrated by other previous studies $(19,20)$. The 
present review examines the mechanisms regulating the role of ERK1/2 in cell senescence and suggests that ERK1/2 is a potentially useful target in treating cancer.

\section{Senescence, ERK1/2 and cell fate}

ERK1/2 signaling pathway. The mammalian MAPKs consist of cytoplasmic serine/threonine kinases that are involved in the transduction of signals from the surface to the interior of the cell. This family includes the ERK family (ERK1-8), the p38 kinase family (p38 $\alpha / \beta / \gamma / \delta)$ and the c-Jun N-terminal kinase family (JNK1-3, additionally termed stress-activated protein kinase) (9). With a number of substrate docking and enzyme recruitment sites (21), ERK1/2 (MAPK1/3) is a multifunctional serine/threonine kinase that is able to phosphorylate numerous substrates, including protein kinases, signal effectors, receptors, cellular scaffold proteins and nuclear transcriptional regulators (21). At present, five types of ERK isoforms are known. ERK1 and ERK2 are thought to be the most important isoforms with $84 \%$ homology for the primary sequences and similar functions (21).

The Ras/Raf/MEK/ERK1/2 signaling pathway is a small GTPase ligation of activated tyrosine receptors and cytoplasmic kinase signal transduction cascades. The key point of activation is to transmit a signal from tyrosine receptors, including epidermal growth factor receptor (EGFR), which subsequently recruit Son of sevenless (SOS) through intracellular Shc and Grb2 domains, ultimately catalyzing the conversion of inactive Ras/guanosine diphosphate to the active Ras/guanosine triphosphate complex (22). As an activator of ERK1/2, MEK1/2 catalyzes the phosphorylation of ERK1/2 at Tyr204/187 and Thr202/185 by casein kinase 2 (CK2) (23). This enzyme subsequently binds to importin7 and translocates ERK1/2 from the cytoplasm to the nucleus (24), where it functions as an upstream regulator of substrate genes that encode for transcription factors, including Elk1, c-Myc, signal transducers and activators of transcription (STATs), c-Jun and c-Fos (21). These transcription factors regulate their counterpart target genes to alter the expression or activity of various proteins and are involved in the regulation of a large variety of processes, including adhesion, cell cycle progression, migration, survival, differentiation, metabolism, proliferation and transcription (21). The Ras/Raf/MEK/ERK cascade is a highly efficient signaling pathway, aided by scaffold proteins, including kinase suppressor of Ras, MEK partner $1 /$ p14 complex, $\beta$-arrestins, fibroblast growth factor receptor substrate 2, MAPK organizer 1 and flotillin-1 (25). The function of scaffold proteins is characterized by combinatorial inhibition, which is the stoichiometry of a scaffold and its signaling partners; the expression levels of scaffold proteins should not be too high (the kinase and its substrate may each bind to an individual scaffold protein) or too low (the phosphorylation of the cascade is sub-optimal) (26). With these different scaffold proteins, the phosphorylation of different isoforms is accurately regulated; the scaffold protein MEK protein 1 specifically binds ERK1, not ERK2 (27).

Role of ERK1/2 in cellular senescence. Cellular senescence was first observed in cultured fibrocytes, when the Hayflick limit demonstrated that as the cells divided, their cell cycle became arrested (replicative senescence) (28). Senescent cells have abnormal metabolic activity (3), accompanied by morphological, biological and genetic alterations. When $\beta$-galactosidase expression (an important senescence marker) increases (29), the cell cycle is arrested at the $\mathrm{G}_{1} / \mathrm{S}$ phase (30). Cell cycle dependent kinase (CDK) and cyclin A activity additionally decrease with increased activity of cyclin-dependent kinase inhibitors (p16INK4a and p21) (31). Without the protection of histones, mitochondrial reactive oxygen species (ROS) may damage mitochondrial DNA, which induces a series of oxidative stress reactions (32). Telomere shortening, which causes DNA to lose protection from the telomeres, is another feature of senescence and leads to DNA integration and degradation. Oxidative stress reactions and mitochondrial dysfunction (33) accelerate the shortening of telomeres. Cellular senescence is triggered by a number of signaling pathways and mechanisms, including DNA injury, telomerase dysfunction, oncogenes, oxidative stress reactions and mitochondrial dysfunction (34).

ERK1/2 is an important messenger for extracellular and intracellular signals, which serve a vital role in processes, including proliferation, differentiation, cytoskeleton construction and cellular senescence (35). In the majority of cases, ERK1/2 is a regulator of cellular proliferation; however, it has been identified that ERK1/2 may additionally promote senescence. Strong, constitutively active expression of MEK1 (an upstream activator of ERK1/2) in non-immortalized intestinal epithelial cells (HIEC cells) promotes cellular senescence, whereas, in immortalized intestinal cells (IEC-6 cells), it does not, suggesting that cell type may serve a role (36). This phenomenon requires further investigation to improve the clinical use of ERK1/2-associated reagents, including ERK1/2 inhibitors.

\section{ERK1/2 promotes cellular proliferation}

ERK1/2 is associated with cell survival, proliferation and development. To investigate the role of ERK1/2 in different cell types and animal models, a number of previous studies investigating this were reviewed. ERK1/2 functions more frequently as a cellular proliferation marker than as a dual role kinase (Table I) (37-54). Based on these previous studies, cellular proliferation is primarily regulated by the effects of ERK1/2 on cell cycle entry and protein synthesis.

DNA and protein synthesis. As a transcription factor regulator, ERK1/2 transduces signals from the cell membrane to the nucleus. ERK1/2 may additionally regulate carbamoyl phosphate synthetase II (55), which catalyzes the initial rate-limiting step in the de novo synthesis of pyrimidine nucleotides. Furthermore, it was identified that ERK1/2 phosphorylates high motility group boxes of nucleolar transcription factor 1, an RNA polymerase I factor transcriptional enhancer that enhances ribosomal RNA genes (56).

Mendoza et al (57) demonstrated that the MEK1/2-ERK1/2 pathway cross-talks with the phosphoinositide 3 kinase $(\mathrm{PI} 3 \mathrm{~K}) /$ protein kinase $\mathrm{B}(\mathrm{AKT}) / \mathrm{mammalian}$ target of rapamycin (mTOR) pathway via cross-inhibition, cross-activation and pathway convergence on substrates. In mouse uterine epithelial cells, activation of protein kinase $C$ by estradiol-17 $\beta$ promotes protein synthesis by activating the ERK-mTOR-40s 


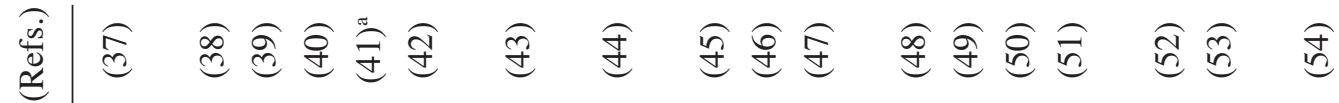

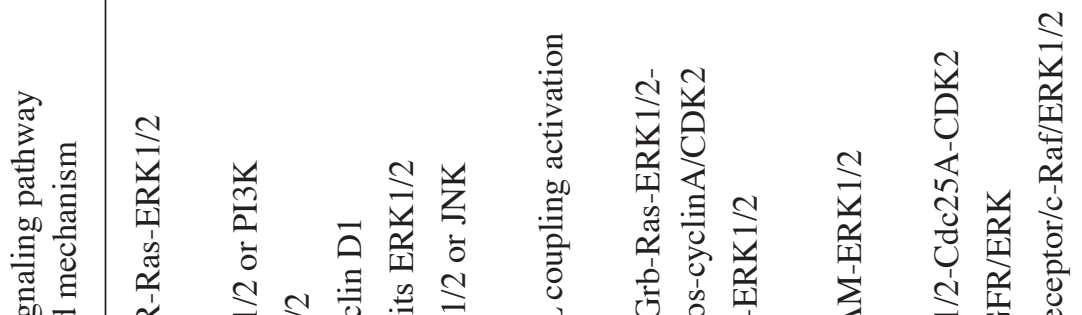

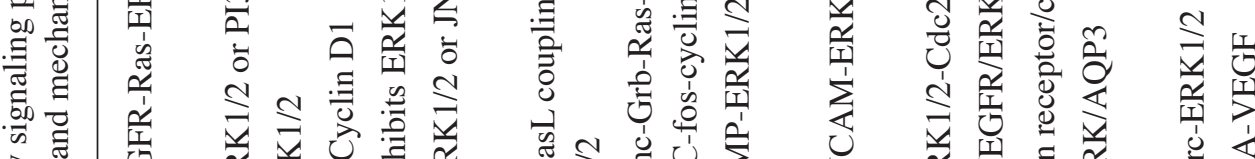

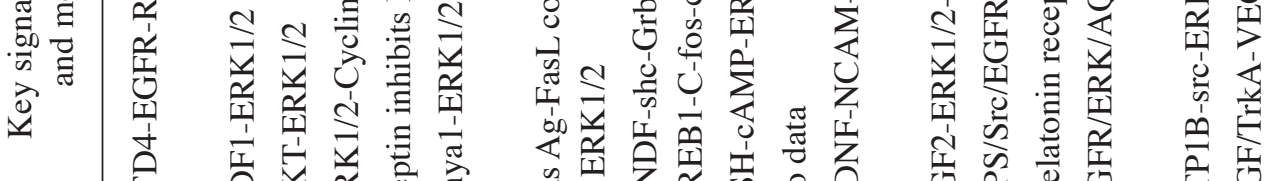

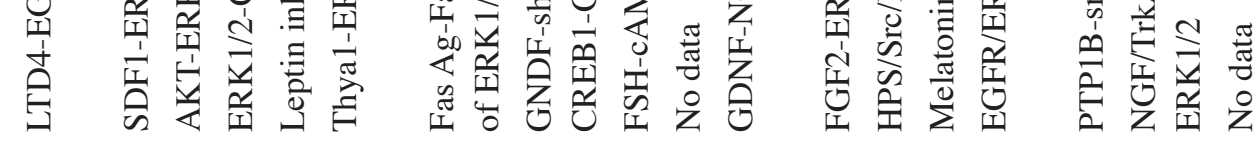

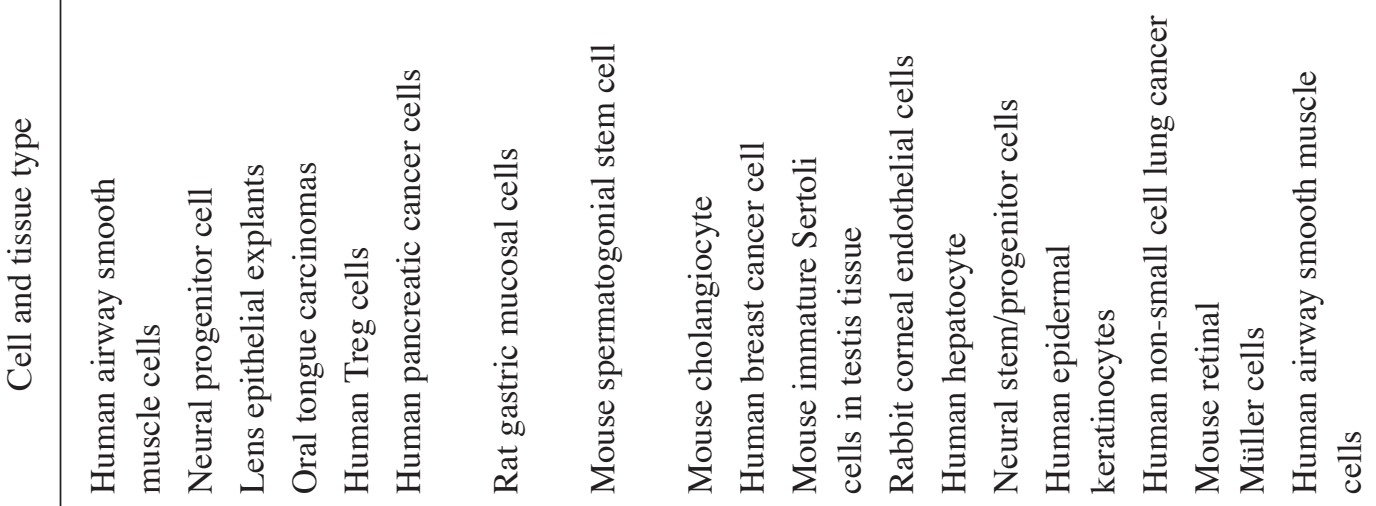

\&

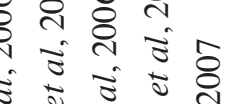

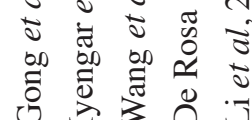

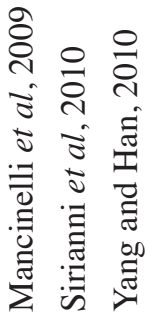

范

ญे

寻 章 㐫惫=

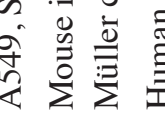


ribosomal protein S6 cascade (58). ERK1 and ERK2 enhance protein translation by increasing the ability of eukaryotic translation factor-4E (59) to recruit protein-synthesizing ribosomes and other protein synthesis initiation factors to the mRNA. This recruitment includes nuclear substrates (ternary complex factor, Elk1, and c-Fos), cytoplasmic substrates [40s ribosomal protein S6 kinase (RSK) family], cytoskeletal proteins and proteins of the nuclear pore complex, many of which serve a direct role in cellular proliferation and development (21). A previous study additionally demonstrated that ERK1/2 may functionally dephosphorylate the tuberous sclerosis 1 and 2 proteins (TSC1/2) complex via its downstream RSK in HEK293 cells (60).

Cell cycle entry. ERK1/2 is involved in $\mathrm{G}_{1} / \mathrm{S}$ and $\mathrm{G}_{2} / \mathrm{M}$ transitions (61). During $\mathrm{G}_{1} / \mathrm{S}$, ERK1/2 regulates cyclin D1 transcription through the Fos family of proteins (62) and Myc $(63,64)$. In $\mathrm{G}_{2} / \mathrm{M}$, ERK1/2 is involved in the nuclear translocation of cyclin B1 by phosphorylating two of four sites within the cytoplasmic retention sequence of cyclin B1 (65) and inhibiting the negative phosphorylation of cell division control protein 2 homolog by myelin transcription factor 1 via RSK2 (66).

In addition to the substrates involved in cell proliferation, ERK1/2 additionally regulates cellular tumor antigen p53 (p53) phosphorylation. p53 is a tumor suppressor protein and functions as a transcription factor by binding to a number of genes, including cyclin-dependent kinase inhibitor $1 \mathrm{~A}$, which encodes p21. p21 binds and inactivates CDKs, which are crucial for cell entry into the $\mathrm{G}_{1} / \mathrm{S}$ phase $(67,68)$. The association between ERK1/2 and $p 53$ remains unclear. A previous study suggested that p53 functions upstream of ERK1/2 (69); however, the most widely accepted hypothesis is that ERK $1 / 2$ regulates p 53 by activating STAT3 (70) and other transcription factors. ERK1/2 and p53 have hundreds of substrates, thus, it is easy for them to engage in crosstalk, as is the case with dual-specificity phosphatases (DUSPs) (71). The effect of ERK1/2 on its downstream substrates may accelerate the degradation of p53 (72). ERK1/2 regulates $\mathrm{p} 53$ phosphorylation [a form that protects p53 from E3 ubiquitin-protein ligase Mdm2 (73)] through the forkhead box M1/c-myc/polycomb complex protein BMI-1 pathway, which inhibits p19 phosphorylation, attenuating cellular senescence (74).

ERK1/2 regulates mitochondria. Mitochondria not only provide energy to cells; however, additionally serve a decisive role in cell fate. Mitochondria within the respiratory chain are responsible for maintaining the proton gradient and providing various respiratory enzymes; it was demonstrated that the proton gradient is not just associated with adenosine triphosphate synthesis. Rasola et al (75) identified that ERK1/2 phosphorylates glycogen synthase kinase- $3 \beta$, inhibiting permeability transition pore opening by regulating cyclophilin D and preventing the release of apoptotic substances, including mitochondrial cytochrome $\mathrm{C}, \mathrm{ROS}, \mathrm{Ca}^{2+}$ and free radicals. The number of mitochondria is additionally an important hallmark of cellular proliferation. A previous study demonstrated that ERK2 may phosphorylate dynamin-1-like protein (an important regulator of mitochondrial fission) on serine 616 in several tumor models (76), resulting in tumor growth.

\section{ERK1/2 promotes cellular senescence through several mechanisms}

Based on extensive investigations in a variety of cell types, previous studies identified that ERK1/2 may additionally facilitate cellular senescence under certain circumstances. In the present review, a number of previous studies are discussed to gain a better understanding of the role of ERK1/2 during cellular senescence and the underlying mechanisms behind its control. In contrast, the role of ERK1/2 in cellular proliferation was only studied in numerous cell types, primarily fibroblasts, providing limited information. The previous studies investigating ERK1/2 involvement in cellular senescence (Table II) (77-90) identified a number of possible mechanisms for the role of ERK1/2 that are associated with abnormal signaling of negative feedback loops, caused by constitutive and overexpressed ERK1/2 (20,77,78), and ERK1/2 cellular localization (79).

Crosstalk and negative feedback loops associated with ERK1/2-induced cellular senescence

Regulation of the MAPK signaling pathway. A number of previous studies demonstrated that negative regulation of ERK1/2 within MAPK signaling cascades regulate ERK1/2 signaling. ERK1/2 phosphorylates proteins within this cascade at alternate sites, which interrupts the normal binding behavior of their respective downstream substrates (91). ERK1/2 phosphorylates EGFR at T669 (92) and decreases constitutive tyrosine phosphorylation activity, decreasing the ability of the phosphorylated loop to cross-activate other adaptors (93). ERK1/2 may additionally phosphorylate dual specificity Cdc25C at T48, which dephosphorylates EGFR at Y1068 (94). Furthermore, ERK1/2 was identified to phosphorylate MAPK signaling components, including fibroblast growth factor receptor (FGFR) at S777 (95); SOS1 at S1132, S1167, S1178 and S1193 (96); fibroblast growth factor receptor substrate 2 (FRS2) $\alpha$ at T132, T135, T138, T376, T452, T455, T458 and T463 (97,98); RAF proto-oncogene serine/threonine-protein kinase (Raf-1) at S29, S289, S296, S301 and S642 (99-103); serine/threonine-protein kinase B-raf (B-Raf) at S151, T401, S750, T753 and S642 (104,105); MEK1 at T292 and T386 (106,107); and kinesin suppressor or Ras 1 at T260, T274, S320, S443 and S463 $(108,109)$ (Fig. 1). The phosphorylation of all these components results in a disruption of binding to downstream substrates.

In other previous study, Fey et al (110) developed a dynamic model of the multiple MAPK cascade interactions and feedback systems of specific proteins of the MAPK pathway using mathematical analysis. Based on their model, p38 inhibits ERK through Ser/Thr protein phosphatase-2A, and JNK restrains p38 and ERK through induction of DUSPs (JNK upregulates transcription of DUSP1; Fig. 1).

Dephosphorylation of ERK1/2. ERK1/2 requires dual phosphorylation of threonine and tyrosine residues to acquire its biological kinase function. Dual-specificity Thr/Tyr phosphatases [DUSPs; additionally termed MAPK phosphatases (MKP)] represent a large family that regulates the activity of MAPKs by dephosphorylating threonine and tyrosine residues within the activation loop of MAPKs, which in turn regulates 


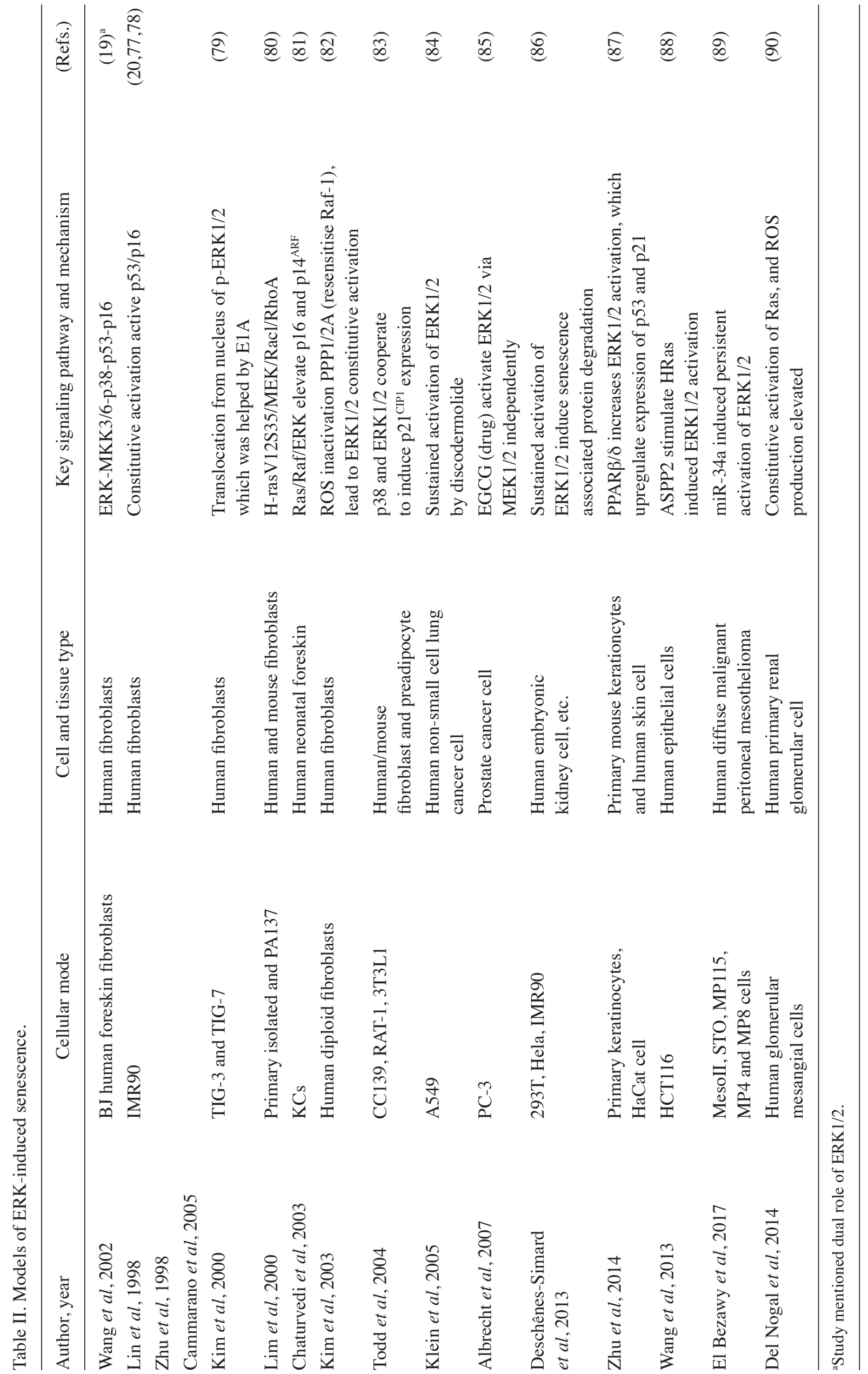




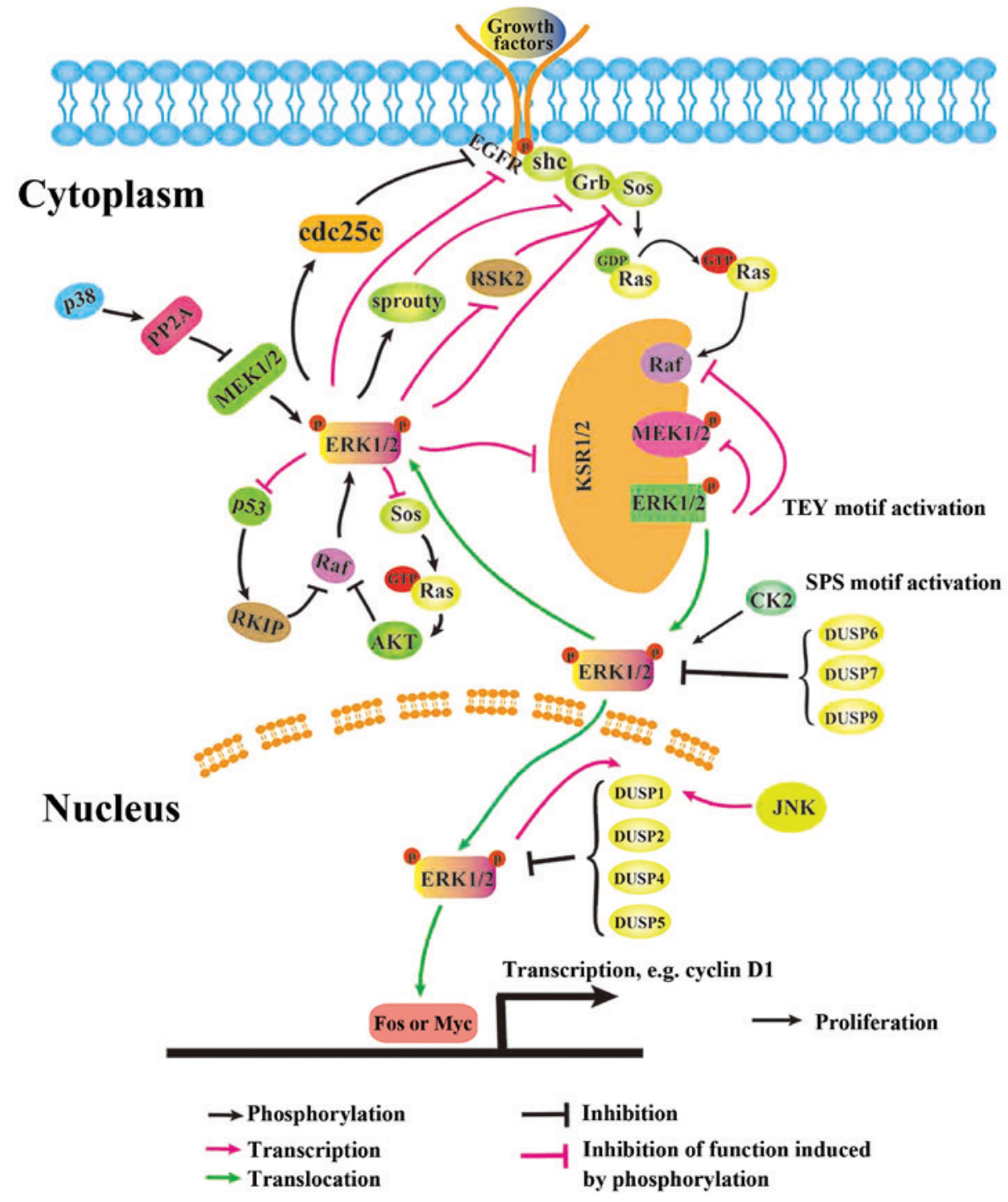

Figure 1. Regulatory system of ERK1/2 signaling. ERK1/2 has a number of substrates, including the MAPK cascade kinases. ERK1/2 may phosphorylate these proteins at numerous sites, which disrupts their normal binding to downstream substrates. Furthermore, ERK1/2 engages in crosstalk with the AKT signaling pathway, p53, DUSPs and Sprys, all of which form a massive regulatory network to tightly regulate ERK1/2 signaling. ERK, extracellular signal-regulated protein kinase; MAPK, mitogen-activated protein kinase; AKT, protein kinase B; DUSPs, dual-specificity phosphatases; Sprys, Sprouty proteins.

the biologically active form of ERK1/2 in the cytoplasm and the nucleus (111). DUSP1, DUSP2, DUSP4 and DUSP5 are located in the nucleus, whereas DUSP6, DUSP7 and DUSP9 are located in the cytoplasm (112). Their binding to ERK1/2 is regulated by a conserved motif within the amino-terminal non-catalytic domain (kinase-interacting motif) of the protein $(113,114)$ and results in a significant increase in catalytic activity, which deprives ERK1/2 of the phosphate group. The interaction between MAPKs and DUSPs is a two-way regulation; MAPKs are able to upregulate transcription of DUSPs (113), primarily those in the cytoplasm (115), in a delayed manner following MAPK activation, whereas, DUSPs strictly regulate MAPK signaling.

Sprouty [protein sprout homolog (Spry) 1-4] is another ERK1/2 regulator family that is not well-studied. A previous Japanese study demonstrated that Spry1 and Spry2 are phosphorylated at Y53 and Y55, which creates a docking site for growth factor receptor-bound protein 2 at the Src homology 2 domain and consequently disrupts association with the FGFR adaptor FRS2 in C2C12 cells (116). Other previous studies suggested that the spry protein inhibits receptor tyrosine kinase signaling, which suppresses the activation of Ras in BRA ${ }^{\mathrm{FV} 600 \mathrm{E}}$ melanomas $(117,118)$. Another previous study demonstrated that in 293T cells, Spry1 and Spry2 regulate Raf-1 by directly binding to it (119). Lake et al (91) suggested that Sprouty serves its functions at multiple nodes in a context-specific manner.

Crosstalk between Ras/ERK1/2 and PI3K/AKT signaling. In contrast to signaling that regulates cell proliferation, AKT/mTOR and ERK1/2 engage in crosstalk that sustains cell proliferation and survival, which in turn helps cells escape from either PI3K/AKT or ERK1/2 suppression (120). Crystal structure analysis demonstrated that astrocytic phosphoprotein PEA-15 (PEA-15) may efficiently bind to the ERK2 activation loop at the Thr-X-Tyr region (121), activating transportation of ERK1/2 from the nucleus. Sinha et al (122) observed that ERK1/2 decreases phosphorylated (p)-AKT expression levels in mouse renal proximal tubular cells via Ras/PI3K through a 


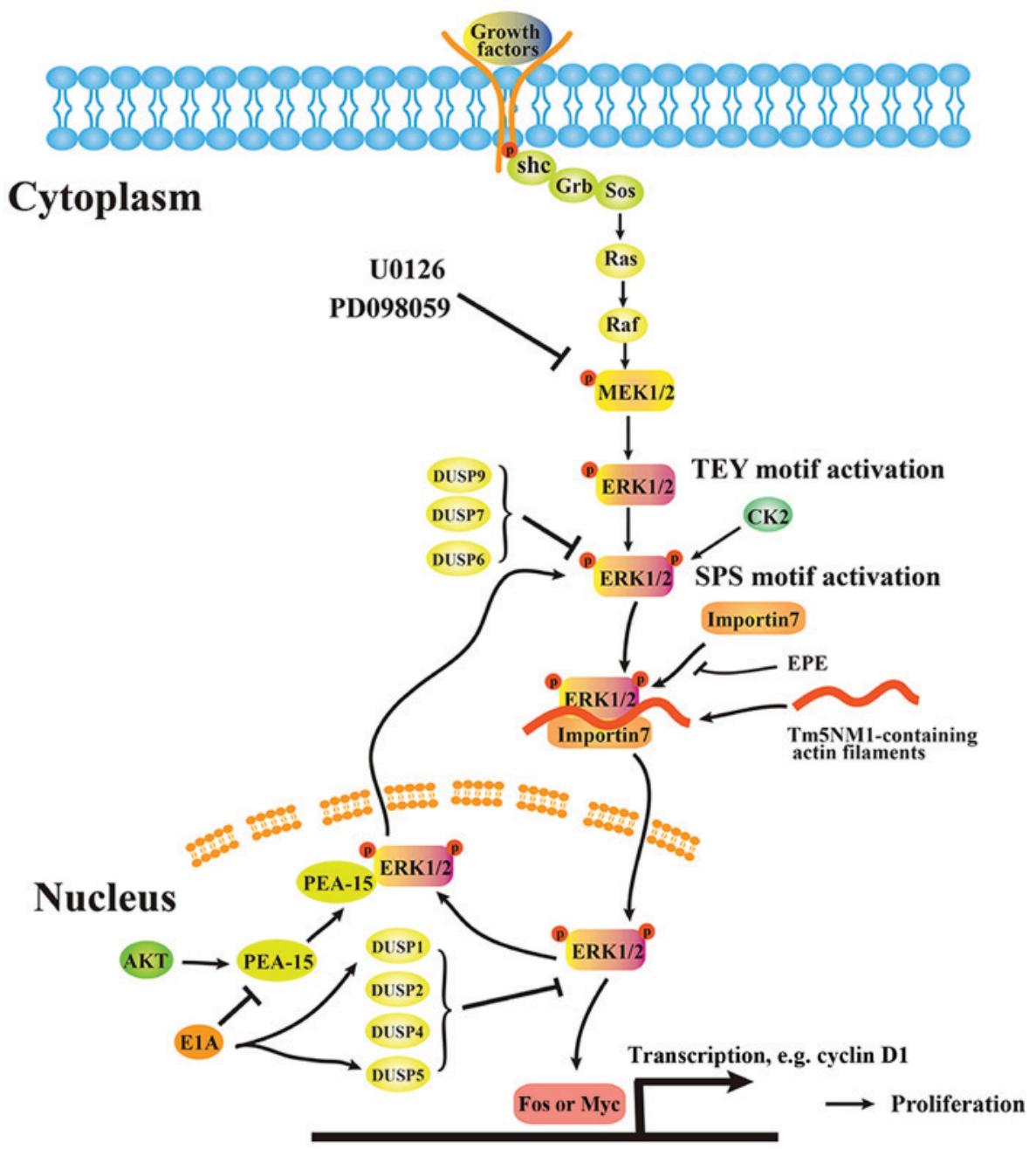

Figure 2. Schema of dynamic translocation of ERK1/2. ERK1/2 translocation from the cytoplasm to the nucleus requires dual activation of the TEY and SPS motifs, followed by binding to Imp7. Subsequently, with the help of Tm5NM1-containing actin filaments, the pSPS-pERK/Imp7/Tm5NM1-containing actin filament complex translocates into the nucleus. Although the cellular localization of ERK1/2 is dynamically regulated, ERK1/2 is exported directly by PEA-15. ERK, extracellular signal-regulated protein kinase; TEY, Thr-Glu-Tyr; SPS, Ser-244/Pro-245/Ser-246; Imp7, importin7; p, phosphorylated; PEA-15, astrocytic phosphoprotein PEA-15.

negative feedback pathway, whereas AKT phosphorylates and stabilizes PEA-15, which subsequently decreases the nuclear localization of ERK1/2 (123) and induces cellular senescence. Although the regulatory nodes shared by Ras/MAPK and PI3K/AKT signaling are complicated, the two signaling pathways are influenced by co-effectors, including TSC1/2, mTOR, ER and S6, and regulate each other in concentrationand context-dependent manners (124).

Crosstalk between ERK1/2 and p53. As a messenger of extracellular and intracellular proteins, ERK1/2 has many substrates. MEK1/2 functions upstream of ERK1/2 and serves a vital regulatory role in ERK1/2 activation. MEK1/ERK signaling promotes cell proliferation, whereas MEK2/ERK signaling promotes $G_{1} / S$ cell cycle arrest (125). In different tissues and cell types, including mouse embryos and fibroblasts, cellular senescence induced by the Ras/Raf/MEK/ERK signaling pathway is dependent on the integrity of p16/INK4A, p21 and p53; in human primary fibroblasts, inhibition of either p16 or p53 is not able to reverse ERK1/2-induced senescence $(17,20,78)$. However, a previous study demonstrated that the matrix cell protein $\mathrm{G} 1 / \mathrm{S}$-specific cyclin $\mathrm{CCN} 1$ induces senescence through the p53/p21 pathway and inhibits lung cancer growth (36). p53 and ERK1/2 have two-way regulation, which means there is a negative feedback loop between ERK1/2 and p53. Lee et al (126) suggested that a novel p53 target protein, Raf kinase inhibitor protein, inhibits ERK1/2 by affecting Raf proteins and promoting senescence. Notably, p53 may regulate the transcription of all nuclear DUSPs (DUSP1/2/4/5) (127-129).

Chemicals or gene mutations lead to ERK1/2-associated senescence. Exposure of cells to certain bioactive chemicals, including the natural ethanolic Rhus coriaria extract may lead to activation of ERK1/2 and p21 upregulation (130). The microtubule stabilizing agent discodermolide was identified to induce cellular senescence due to overexpressed ERK1/2 in A549 cells (66). Administration of epigallocatechin-3-gallate leads to cellular senescence during PC-3 prostate cancer cell proliferation via MEK-independent ERK1/2 activation (85). In addition, a Ras or B-Raf mutation is common in tumors, particularly in malignant tumors, which may lead to sustained 
activation of ERK1/2 signaling. In specific cases, downstream proteins are activated by ERK1/2 aberrantly, resulting in different physiological effects (103). Expression of proteins downstream of ERK1/2, including BRAF-induced insulin-like grow th factor-binding protein 7 (IGFBP7) in normal melanoma cells, is low and primarily controlled by autocrine or paracrine functions that influence cell proliferation (103). Examples of such phenomenon include BRAFV600E-positive nevi, which contain high BRAF expression; the continuously activated RAF/MEK/ERK pathway, which increases IGFBP7 expression; and high expression levels of IGFBP7, which inhibit the RAF/MEK/ERK pathway within cells. However, in melanoma cells, IGFBP7 expression is lost, which results in uncontrolled proliferation (131).

Relationship between ERK1/2 and micro (mi)RNAs. miRNAs are important for regulating cell biology. Previous studies demonstrated that miRNA-34a induces persistent activation of ERK1/2, leading to cellular senescence via inhibition of p53 signaling (89) and MEK1/2 (132). miR-21 increases the expression level of p-ERK1/2 by inhibiting Spry1 (116) and Spry2 (133).

\section{Cellularlocalizationanddurationinfluence ERK1/2-associated} cell fate

Negative feedback occurs when ERKI/2 is overexpressed. A number of previous studies suggest thatERK1/2-induced cellular senescence may be associated with the strength of ERK1/2 signals and the duration of its activation $(20,77,78,86,90,134)$. As ERK1/2 has many substrates, different biological effects may occur when the signal proteins compete for the same target protein. As discussed above, many negative feedback loops and regulatory nodes shape ERK1/2 signaling, and when ERK1/2 is overexpressed, it may activate those negative loops. However, this regulatory system is dependent on the cellular context.

Translocation from the cytoplasm to the nucleus determines the role of $E R K 1 / 2$. Scaffold proteins facilitate protein translocation, and translocation of ERK1/2 from the cytoplasm to the nucleus is essential for regulation of the cell cycle and cellular proliferation (135). This process requires dual-phosphorylation of specific residues within the activation loop. ERK is initially phosphorylated by MAPK/ERK kinase (MEK) on the Thr-Glu-Tyr motif, with subsequent phosphorylation on the Ser-244/Pro-245/Ser-246 (SPS) nuclear translocation sequence (NTS) $(108,109)$. This is achieved primarily by CK2 to generate pSPS-pERK, which binds to the shuttling protein importin7 (Imp7) $(136,137)$. A previous study investigating mouse embryo fibroblasts demonstrated that Tm5NM1-containing actin filaments facilitate the binding of pSPS-pERK (Ser-244/Pro-245/Ser-246) and Imp7, possibly by functioning as a scaffold and/or recruiting myosin motors to assist in the physical transportation of pSPS-pERK from the cytoplasm to the nucleus (136). Inhibiting the binding of pSPS-pERK and Imp7 appears to be an effective way of blocking the translocation of dual-phosphorylated ERK. Plotnikov et al (135) developed a myristoylated, NTS-derived phosphomimetic peptide (EPE peptide) that competes with the binding of Imp7 and blocks this process in a number of cell lines.
ETS translocation variant 4 (E1A) is additionally a negative regulator of activated ERK1/2 translocation from the cytoplasm to the nucleus $(79,138)$. A previous study examining normal human diploid fibroblast IMR90 cells demonstrated that E1A decreases expression levels of PEA-15 (139), an ERK1/2 nuclear export factor, and increases expression levels of MKP1/DUSP1 and DUSP5 (138). The translocation regulation model is presented in Fig. 2.

\section{Conclusion}

ERK1/2 serves a vital role in cellular outcomes, which involve numerous substrates, regulators and scaffolding proteins. If a small dose of a MEK1/2 inhibitor, including U0126 or PD098059, is applied to a cell, the cell will recover by utilizing a compensatory pathway to regain its proliferation capacity. Even in the same type of cell or animal model, ERK1/2 serves a dual role in cellular senescence under different circumstances, which are dose- and duration-dependent. Cells subjected to drugs against ERK1/2 may additionally contain mutations in upstream (AKT, MEK and Ras/Raf) or downstream (p21 and p53) proteins. Analyzing cells for Ras/Raf/MAPK mutations and testing cell sensitivity may help to determine the proper dosage and duration of drug administration. In terms of drug development, altering the translocation of ERK1/2 from the cytoplasm to the nucleus (135), which is primarily required for induction of cell proliferation, may help to decrease the proliferation of cancer cells. However, as cells may shift their proliferation signals between a number of different proteins, a combination of numerous anti-proliferation tactics require consideration.

\section{Acknowledgements}

Not applicable.

\section{Funding}

The present study was supported by the National Natural Science Foundation of China (grant nos. 81460374, 31460304 and 81572753), the Natural Science Foundation of Jiangxi Province of China (grant nos. 20171BAB205062 and 20171BCB23086) and the Education Department of Jiangxi Province of China (grant no. 160032).

\section{Availability of data and materials}

Not applicable.

\section{Authors' contributions}

JZ and TL contributed equally in reviewing the publications and writing this manuscript. PG and DH drafted the manuscript. JY, QX, YL and RK designed the schema of ERK1/2 signaling. All authors read and approved the final version of the manuscript.

\section{Ethics approval and consent to participate}

Not applicable. 


\section{Patient consent for publication}

Not applicable.

\section{Competing interests}

The authors declare that they have no competing interests.

\section{References}

1. Cristofalo VJ, Lorenzini A, Allen RG, Torres C and Tresini M: Replicative senescence: A critical review. Mech Ageing Dev 125: 827-848, 2004.

2. Zeiser R: Trametinib. Recent Results Cancer Res 201: 241-248, 2014.

3. Salama R, Sadaie M, Hoare M and Narita M: Cellular senescence and its effector programs. Genes Dev 28: 99-114, 2014.

4. Tominaga K: The emerging role of senescent cells in tissue homeostasis and pathophysiology. Pathobiol Aging Age Relat Dis 5: 27743, 2015.

5. Gewirtz DA: Autophagy and senescence in cancer therapy. J Cell Physiol 229: 6-9, 2014.

6. Ohtani N, Mann DJ and Hara E: Cellular senescence: Its role in tumor suppression and aging. Cancer Sci 100: 792-797, 2009.

7. Wu CH, van Riggelen J, Yetil A, Fan AC, Bachireddy P and Felsher DW: Cellular senescence is an important mechanism of tumor regression upon c-Myc inactivation. Proc Natl Acad Sci USA 104: 13028-13033, 2007.

8. Roberts PJ and Der CJ: Targeting the Raf-MEK-ERK mitogen-activated protein kinase cascade for the treatment of cancer. Oncogene 26: 3291-3310, 2007.

9. Plotnikov A, Zehorai E, Procaccia S and Seger R: The MAPK cascades: Signaling components, nuclear roles and mechanisms of nuclear translocation. Biochim Biophys Acta 1813: 1619-1633, 2011.

10. Tan X, Wang YL, Yang XL and Zhang DD: Ethyl acetate extract of Artemisia anomala S. Moore displays potent anti-inflammatory effect. Evid Based Complement Alternat Med 2014: 681352, 2014.

11. Montero-Conde C, Ruiz-Llorente S, Dominguez JM, Knauf JA, Viale A, Sherman EJ, Ryder M, Ghossein RA, Rosen N and Fagin JA: Relief of feedback inhibition of HER3 transcription by RAF and MEK inhibitors attenuates their antitumor effects in BRAF-mutant thyroid carcinomas. Cancer Discov 3: 520-533, 2013.

12. Bell RM, Kunuthur SP, Hendry C, Bruce-Hickman D, Davidson S and Yellon DM: Matrix metalloproteinase inhibition protects CyPD knockout mice independently of RISK/mPTP signalling: A parallel pathway to protection. Basic Res Cardiol 108: 331 , 2013.

13. Wu J, Xu J, Eksioglu EA, Chen X, Zhou J, Fortenbery N, Wei $\mathrm{S}$ and Dong J: Icariside II induces apoptosis of melanoma cells through the downregulation of survival pathways. Nutr Cancer 65: 110-117, 2013.

14. Desar IM, Gilles R, van Herpen CM, Timmer-Bonte AJ, Cantarini MV, van der Graaf WT and Oyen WJ: (18)F-FLT-PET for response evaluation of MEK inhibitor selumetinib (AZD6244, ARRY-142886) in patients with solid tumors. World J Nucl Med 11: 65-69, 2012.

15. Barlin JN, Jelinic P, Olvera N, Bogomolniy F, Bisogna M, Dao F, Barakat RR, Chi DS and Levine DA: Validated gene targets associated with curatively treated advanced serous ovarian carcinoma. Gynecol Oncol 128: 512-517, 2013.

16. Rybakova Y, Akkuratov E, Kulebyakin K, Brodskaya O Dizhevskaya A and Boldyrev A: Receptor-mediated oxidative stress in murine cerebellar neurons is accompanied by phosphorylation of MAP (ERK 1/2) kinase. Curr Aging Sci 5 : 225-230, 2012

17. Zhuang D, Mannava S, Grachtchouk V, Tang WH, Patil S, Wawrzyniak JA, Berman AE, Giordano TJ, Prochownik EV, Soengas MS and Nikiforov MA: C-MYC overexpression is required for continuous suppression of oncogene-induced senescence in melanoma cells. Oncogene 27: 6623-6634, 2008

18. Wang D, Boerner SA, Winkler JD and LoRusso PM: Clinical experience of MEK inhibitors in cancer therapy. Biochim Biophys Acta 1773: 1248-1255, 2007.
19. Wang W, Chen JX, Liao R, Deng Q, Zhou JJ, Huang S and Sun P: Sequential activation of the MEK-extracellular signal-regulated kinase and MKK3/6-p38 mitogen-activated protein kinase pathways mediates oncogenic ras-induced premature senescence. Mol Cell Biol 22: 3389-3403, 2002.

20. Lin AW, Barradas M, Stone JC, van Aelst L, Serrano M and Lowe SW: Premature senescence involving p53 and p16 is activated in response to constitutive MEK/MAPK mitogenic signaling. Genes Dev 12: 3008-3019, 1998.

21. Roskoski R Jr: ERK1/2 MAP kinases: Structure, function, and regulation. Pharmacol Res 66: 105-143, 2012.

22. Gureasko J, Galush WJ, Boykevisch S, Sondermann H, Bar-Sagi D, Groves JT and Kuriyan J: Membrane-dependent signal integration by the Ras activator Son of sevenless. Nat Struct Mol Biol 15: 452-461, 2008.

23. Chuderland D, Konson A and Seger R: Identification and characterization of a general nuclear translocation signal in signaling proteins. Mol Cell 31: 850-861, 2008.

24. Matsubayashi Y, Fukuda M and Nishida E: Evidence for existence of a nuclear pore complex-mediated, cytosol-independent pathway of nuclear translocation of ERK MAP kinase in permeabilized cells. J Biol Chem 276: 41755-41760, 2001.

25. Meister M, Tomasovic A, Banning A and Tikkanen R: Mitogen-activated protein (MAP) kinase scaffolding proteins: A recount. Int J Mol Sci 14: 4854-4884, 2013.

26. Good MC, Zalatan JG and Lim WA: Scaffold proteins: Hubs for controlling the flow of cellular information. Science 332: 680-686, 2011.

27. Schaeffer HJ, Catling AD, Eblen ST, Collier LS, Krauss A and Weber MJ: MP1: A MEK binding partner that enhances enzymatic activation of the MAP kinase cascade. Science 281: 1668-1671, 1998.

28. Hayflick L and Moorhead PS: The serial cultivation of human diploid cell strains. Exp Cell Res 25: 585-621, 1961.

29. Yang NC and $\mathrm{Hu}$ ML: The limitations and validities of senescence associated-beta-galactosidase activity as an aging marker for human foreskin fibroblast Hs68 cells. Exp Gerontol 40: 813-819, 2005

30. Chen KY: Transcription factors and the down-regulation of G1/S boundary genes in human diploid fibroblasts during senescence. Front Biosci 2: d417-d426, 1997.

31. Hernandez-Segura A, Nehme J and Demaria M: Hallmarks of cellular senescence. Trends Cell Biol 28: 436-453, 2018.

32. Passos JF and von Zglinicki T: Mitochondria, telomeres and cell senescence. Exp Gerontol 40: 466-472, 2005.

33. Liu L, Trimarchi JR, Smith PJ and Keefe DL: Mitochondrial dysfunction leads to telomere attrition and genomic instability. Aging cell 1: 40-46, 2002.

34. Campisi J: Cellular senescence as a tumor-suppressor mechanism. Trends Cell Biol 11: S27-S31, 2001.

35. Sun Y, Liu WZ, Liu T, Feng X, Yang N and Zhou HF: Signaling pathway of MAPK/ERK in cell proliferation, differentiation, migration, senescence and apoptosis. J Recept Signal Transduct Res 35: 600-604, 2015.

36. Boucher MJ, Jean D, Vézina A and Rivard N: Dual role of MEK/ERK signaling in senescence and transformation of intestinal epithelial cells. Am J Physiol Gastrointest Liver Physiol 286: G736-G746, 2004.

37. Ravasi S, Citro S, Viviani B, Capra V and Rovati GE: CysLT1 receptor-induced human airway smooth muscle cells proliferation requires ROS generation, EGF receptor transactivation and ERK1/2 phosphorylation. Respir Res 7: 42, 2006.

38. Gong X, He X, Qi L, Zuo H and Xie Z: Stromal cell derived factor-1 acutely promotes neural progenitor cell proliferation in vitro by a mechanism involving the ERK1/2 and PI-3K signal pathways. Cell Biol Int 30: 466-471, 2006.

39. Iyengar L, Patkunanathan B, Lynch OT, McAvoy JW, Rasko JE and Lovicu FJ: Aqueous humour- and growth factor-induced lens cell proliferation is dependent on MAPK/ERK1/2 and Akt/PI3-K signalling. Exp Eye Res 83: 667-678, 2006.

40. Wang L, Liu T, Nishioka M, Aguirre RL, Win SS and Okada N: Activation of ERK1/2 and cyclin D1 expression in oral tongue squamous cell carcinomas: Relationship between clinicopathological appearances and cell proliferation. Oral Oncol 42: 625-631, 2006

41. De Rosa V, Procaccini C, Cali G, Pirozzi G, Fontana S, Zappacosta S, La Cava A and Matarese G: A key role of leptin in the control of regulatory $\mathrm{T}$ cell proliferation. Immunity 26 : 241-255, 2007. 
42. Li M, Feurino LW, Li F, Wang H, Zhai Q, Fisher WE, Chen C and Yao Q: Thymosinalphal stimulates cell proliferation by activating ERK1/2, JNK, and increasing cytokine secretion in human pancreatic cancer cells. Cancer Lett 248: 58-67, 2007.

43. Li H, Cai X, Fan X, Moquin B, Stoicov C and Houghton J: Fas Ag-FasL coupling leads to ERK1/2-mediated proliferation of gastric mucosal cells. Am J Physiol Gastrointest Liver Physiol 294: G263-G275, 2008.

44. He Z, Jiang J, Kokkinaki M, Golestaneh N, Hofmann MC and Dym M: Gdnf upregulates c-Fos transcription via the Ras/Erk1/2 pathway to promote mouse spermatogonial stem cell proliferation. Stem Cells 26: 266-278, 2008.

45. Mancinelli R, Onori P, Gaudio E, DeMorrow S, Franchitto A, Francis H, Glaser S, Carpino G, Venter J, Alvaro D, et al: Follicle-stimulating hormone increases cholangiocyte proliferation by an autocrine mechanism via cAMP-dependent phosphorylation of ERK1/2 and Elk-1. Am J Physiol Gastrointest Liver Physiol 297: G11-G26, 2009.

46. Sirianni R, Chimento A, De Luca A, Casaburi I, Rizza P, Onofrio A, Iacopetta D, Puoci F, Andò S, Maggiolini M and Pezzi V: Oleuropein and hydroxytyrosol inhibit MCF-7 breast cancer cell proliferation interfering with ERK1/2 activation. Mol Nutr 54: 833-840, 2010

47. Yang Y and Han C: GDNF stimulates the proliferation of cultured mouse immature Sertoli cells via its receptor subunit NCAM and ERK1/2 signaling pathway. BMC Cell $\neq \neq \neq$ Bio $\neq \neq$.

48. Lee JG and Kay EP: PI 3-kinase/Racl and ERK1/2 regulate FGF-2-mediated cell proliferation through phosphorylation of p27 at Ser10 by KIS and at Thr187 by Cdc25A/Cdk2. Invest Ophthalmol Vis Sci 52: 417-426, 2011.

49. Gao M, Zhan YQ, Yu M, Ge CH, Li CY, Zhang JH, Wang XH Ge ZQ and Yang XM: Hepassocin activates the EGFR/ERK cascade and induces proliferation of L02 cells through the Src-dependent pathway. Cell Signal 26: 2161-2166, 2014.

50. Tocharus C, Puriboriboon Y, Junmanee T, Tocharus J, Ekthuwapranee K and Govitrapong P: Melatonin enhances adult rat hippocampal progenitor cell proliferation via ERK signaling pathway through melatonin receptor. Neuroscience 275: 314-321, 2014.

51. Wu Z, Uchi H, Morino-Koga S, Shi W and Furue $\mathrm{M}$ Resveratrol inhibition of human keratinocyte proliferation via SIRT1/ARNT/ERK dependent downregulation of aquaporin 3. J Dermatol Sci 75: 16-23, 2014.

52. Liu H, Wu Y, Zhu S, Liang W, Wang Z, Wang Y, Lv T, Yao Y, Yuan D and Song Y: PTP1B promotes cell proliferation and metastasis through activating src and ERK1/2 in non-small cell lung cancer. Cancer Lett 359: 218-225, 2015.

53. Wang J, He C, Zhou T, Huang Z, Zhou L and Liu X: NGF increases VEGF expression and promotes cell proliferation via ERK1/2 and AKT signaling in Müller cells. Mol Vis 22: 254-263, 2016.

54. Kim SH, Pei QM, Jiang P, Yang M, Qian XJ and Liu JB: Effect of active vitamin D3 on VEGF-induced ADAM33 expression and proliferation in human airway smooth muscle cells: Implications for asthma treatment. Respir Res 18: 7, 2017.

55. Graves LM, Guy HI, Kozlowski P, Huang M, Lazarowski E Pope RM, Collins MA, Dahlstrand EN, Earp HS III and Evans DR: Regulation of carbamoyl phosphate synthetase by MAP kinase. Nature 403: 328-332, 2000

56. Stefanovsky V, Langlois F, Gagnon-Kugler T, Rothblum LI and Moss T: Growth factor signaling regulates elongation of RNA polymerase I transcription in mammals via UBF phosphorylation and r-chromatin remodeling. Mol Cell 21: 629-639, 2006.

57. Mendoza MC,ErEE and Blenis J: The Ras-ERK and PI3K-mTOR pathways: Cross-talk and compensation. Trends Biochem Sci 36: 320-328, 2011

58. Wang Y, Zhu L, Kuokkanen S and Pollard JW: Activation of protein synthesis in mouse uterine epithelial cells by estradiol-17 $\beta$ is mediated by a PKC-ERK1/2-mTOR signaling pathway. Proc Natl Acad Sci USA 112: E1382-E1391, 2015.

59. Hoang B, Benavides A, Shi Y, Yang Y, Frost P, Gera J and Lichtenstein A: The PP242 mammalian target of rapamycin (mTOR) inhibitor activates extracellular signal-regulated kinase (ERK) in multiple myeloma cells via a target of rapamycin complex 1 (TORC1)/eukaryotic translation initiation factor 4E (eIF-4E)/RAF pathway and activation is a mechanism of resistance. J Biol Chem 287: 21796-21805, 2012 .
60. Ma L, Chen Z, Erdjument-Bromage H, Tempst P and Pandolfi PP: Phosphorylation and functional inactivation of TSC2 by Erk implications for tuberous sclerosis and cancer pathogenesis. Cell 121: 179-193, 2005

61. Chambard JC, Lefloch R, Pouysségur J and Lenormand P: ERK implication in cell cycle regulation. Biochim Biophys Acta 1773: 1299-1310, 2007

62. Lavoie JN, L'Allemain G, Brunet A, Muller R and Pouysségur J: Cyclin D1 expression is regulated positively by the p42/p44MAPK and negatively by the p38/HOGMAPK pathway. J Biol Chem 271: 20608-20616, 1996

63. Seth A, Alvarez E, Gupta S and Davis RJ: A phosphorylation site located in the NH2-terminal domain of c-Myc increases transactivation of gene expression. J Biol Chem 266: 23521-23524, 1991.

64. Daksis JI, Lu RY, Facchini LM, Marhin WW and Penn LJ: Myc induces cyclin D1 expression in the absence of de novo protein synthesis and links mitogen-stimulated signal transduction to the cell cycle. Oncogene 9: 3635-3645, 1994.

65. Walsh S, Margolis SS and Kornbluth S: Phosphorylation of the cyclin B1 cytoplasmic retention sequence by mitogen-activated protein kinase and Plx. Mol Cancer Res 1: 280-289, 2003.

66. Palmer A, Gavin AC and Nebreda AR: A link between MAP kinase and p34(cdc2)/cyclin B during oocyte maturation: p90(rsk) phosphorylates and inactivates the p34(cdc2) inhibitory kinase Myt1. EMBO J 17: 5037-5047, 1998.

67. Shaw PH: The role of p53 in cell cycle regulation. Pathol Res Pract 192: 669-675, 1996.

68. Wesierska-Gadek J, Wojciechowski J, Ranftler C and Schmid G: Role of p53 tumor suppressor in ageing: Regulation of transient cell cycle arrest and terminal senescence. J Physiol Pharmacol 56: 15-28, 2005.

69. Lee SY, Choi HC, Choe YJ, Shin SJ, Lee SH and Kim HS: Nutlin-3 induces BCL2A1 expression by activating ELK1 through the mitochondrial p53-ROS-ERK1/2 pathway. Int J Oncol 45: 675-682, 2014.

70. Murase S, Kim E, Lin L, Hoffman DA and McKay RD: Loss of signal transducer and activator of transcription 3 (STAT3) signaling during elevated activity causes vulnerability in hippocampal neurons. J Neurosci 32: 15511-15520, 2012.

71. Carlos AR, Escandell JM, Kotsantis P, Suwaki N, Bouwman P, Badie S, Folio C, Benitez J, Gomez-Lopez G, Pisano DG, et al: ARF triggers senescence in Brca2-deficient cells by altering the spectrum of p53 transcriptional targets. Nat Commun 4: 2697 , 2013.

72. Tang D, Wu D, Hirao A, Lahti JM, Liu L, Mazza B, Kidd VJ, Mak TW and Ingram AJ: ERK activation mediates cell cycle arrest and apoptosis after DNA damage independently of p53. J Biol Chem 277: 12710-12717, 2002.

73. Ashcroft $\mathrm{M}$ and Vousden $\mathrm{KH}$ : Regulation of p53 stability. Oncogene 18: 7637-7643, 1999

74. Ling Q, Meng C, Chen Q and Xing D: Activated ERK/FOXM1 pathway by low-power laser irradiation inhibits UVB-induced senescence through down-regulating p21 expression. J Cell Physiol 229: 108-116, 2014

75. Rasola A, Sciacovelli M, Pantic B and Bernardi P: Signal transduction to the permeability transition pore. FEBS Lett 584 1989-1996, 2010

76. Kashatus JA, Nascimento A, Myers LJ, Sher A, Byrne FL, Hoehn KL, Counter CM and Kashatus DF: Erk2 phosphorylation of Drpl promotes mitochondrial fission and MAPK-driven tumor growth. Mol Cell 57: 537-551, 2015.

77. Zhu J, Woods D, McMahon M and Bishop JM: Senescence of human fibroblasts induced by oncogenic Raf. Genes Dev 12: 2997-3007, 1998

78. Cammarano MS, Nekrasova T, Noel B and Minden A: Pak4 induces premature senescence via a pathway requiring p16INK4/p19ARF and mitogen-activated protein kinase signaling. Mol Cell Biol 25: 9532-9542, 2005.

79. Kim-Kaneyama, Nose K and Shibanuma M: Significance of nuclear relocalization of ERK1/2 in reactivation of c-fos transcription and DNA synthesis in senescent fibroblasts. J Biol Chem 275: 20685-20692, 2000.

80. Lim IK, Won Hong K, Kwak IH, Yoon G and Park SC: Cytoplasmic retention of $\mathrm{p}$-Erk1/2 and nuclear accumulation of actin proteins during cellular senescence in human diploid fibroblasts. Mech Ageing Dev 119: 113-130, 2000.

81. Chaturvedi V, Cesnjaj M, Bacon P, Panella J, Choubey D, Diaz MO and Nickoloff BJ: Role of INK4a/Arf locus-encoded senescent checkpoints activated in normal and psoriatic keratinocytes. Am J Pathol 162: 161-170, 2003. 
82. Kim HS, Song MC, Kwak IH, Park TJ and Lim IK: Constitutive induction of $\mathrm{p}$-Erk $1 / 2$ accompanied by reduced activities of protein phosphatases 1 and 2A and MKP3 due to reactive oxygen species during cellular senescence. J Biol Chem 278: 37497-37510, 2003.

83. Todd DE, Densham RM, Molton SA, Balmanno K, Newson C, Weston CR, Garner AP, Scott L and Cook SJ: ERK1/2 and p38 cooperate to induce a p21CIP1-dependent G1 cell cycle arrest. Oncogene 23: 3284-3295, 2004.

84. Klein LE, Freeze BS, Smith AB III and Horwitz SB: The microtubule stabilizing agent discodermolide is a potent inducer of accelerated cell senescence. Cell Cycle 4: 501-507, 2005.

85. Albrecht DS, Clubbs EA, Ferruzzi $M$ and Bomser JA: Epigallocatechin-3-gallate (EGCG) inhibits PC-3 prostate cancer cell proliferation via MEK-independent ERK1/2 activation. Chem Biol Interact 171: 89-95, 2008.

86. Deschênes-Simard X, Gaumont-Leclerc MF, Bourdeau V, Lessard F, Moiseeva O, Forest V, Igelmann S, Mallette FA, Saba-El-Leil MK, Meloche S, et al: Tumor suppressor activity of the ERK/MAPK pathway by promoting selective protein degradation. Genes Dev 27: 900-915, 2013.

87. Zhu B, Ferry CH, Blazanin N, Bility MT, Khozoie C, Kang BH, Glick AB, Gonzalez FJ and Peters JM: PPAR $\beta / \delta$ promotes HRAS-induced senescence and tumor suppression by potentiating p-ERK and repressing p-AKT signaling. Oncogene 33: 5348-5359, 2014.

88. WangZ,Liu Y,TakahashiM,VanHookK,Kampa-SchittenhelmKM, Sheppard BC, Sears RC, Stork PJ and Lopez CD: N terminus of ASPP2 binds to Ras and enhances Ras/Raf/MEK/ERK activation to promote oncogene-induced senescence. Proc Natl Acad Sci USA 110: 312-317, 2013

89. El Bezawy R, De Cesare M, Pennati M, Deraco M, Gandellini P, Zuco V and Zaffaroni N: Antitumor activity of miR-34a in peritoneal mesothelioma relies on c-MET and AXL inhibition: Persistent activation of ERK and AKT signaling as a possible cytoprotective mechanism. J Hematol Oncol 10: 19, 2017.

90. del Nogal M, Troyano N, Calleros L, Griera M, Rodriguez-Puyol M, Rodriguez-Puyol D and Ruiz-Torres MP Hyperosmolarity induced by high glucose promotes senescence in human glomerular mesangial cells. Int J Biochem Cell Biol 54 98-110, 2014.

91. Lake D, Correa SA and Müller J: Negative feedback regulation of the ERK1/2 MAPK pathway. Cell Mol Life Sci 73: 4397-4413, 2016

92. Northwood IC, Gonzalez FA, Wartmann M, Raden DL and Davis RJ: Isolation and characterization of two growth factor-stimulated protein kinases that phosphorylate the epidermal growth factor receptor at threonine 669. J Biol Chem 266: 15266-15276, 1991.

93. Sato K, Shin MS, Sakimura A, Zhou Y, Tanaka T, Kawanishi M, Kawasaki Y, Yokoyama S, Koizumi K, Saiki I and Sakurai H: Inverse correlation between Thr-669 and constitutive tyrosine phosphorylation in the asymmetric epidermal growth factor receptor dimer conformation. Cancer Sci 104: 1315-1322, 2013.

94. Prahallad A, Sun C, Huang S, Di Nicolantonio F, Salazar R, Zecchin D, Beijersbergen RL, Bardelli A and Bernards R: Unresponsiveness of colon cancer to BRAF(V600E) inhibition through feedback activation of EGFR. Nature 483: 100-103, 2012.

95.Zakrzewska M, Haugsten EM, Nadratowska-Wesolowska B Oppelt A, Hausott B, Jin Y, Otlewski J, Wesche J and Wiedlocha A: ERK-mediated phosphorylation of fibroblast growth factor receptor 1 on Ser777 inhibits signaling. Sci Signal 6: ra11, 2013.

96. Kamioka Y, Yasuda S, Fujita Y, Aoki K and Matsuda M: Multiple decisive phosphorylation sites for the negative feedback regulation of SOS1 via ERK. J Biol Chem 285: 33540-33548, 2010.

97. Lax I, Wong A, Lamothe B, Lee A, Frost A, Hawes J and Schlessinger J: The docking protein FRS2alpha controls a MAP kinase-mediated negative feedback mechanism for signaling by FGF receptors. Mol Cell 10: 709-719, 2002.

98. Wu YJ, Chen ZJ and Ullrich A: EGFR and FGFR signaling through FRS2 is subject to negative feedback control by ERK1/2. Biol Chem 384: 1215-1226, 2003.

99. Wartmann M, Hofer P, Turowski P, Saltiel AR and Hynes NE: Negative modulation of membrane localization of the Raf-1 protein kinase by hyperphosphorylation. J Biol Chem 272 3915-3923, 1997.

100. Weiss RH, Maga EA and Ramirez A: MEK inhibition augments Raf activity, but has variable effects on mitogenesis, in vascular smooth muscle cells. Am J Physiol 274: C1521-C1529, 1998.
101. Dougherty MK, Müller J, Ritt DA, Zhou M, Zhou XZ, Copeland TD, Conrads TP, Veenstra TD, Lu KP and Morrison DK Regulation of Raf-1 by direct feedback phosphorylation. Mol Cell 17: 215-224, 2005.

102. Hekman M, Fischer A, Wennogle LP, Wang YK, Campbell SL and Rapp UR: Novel C-Raf phosphorylation sites: Serine 296 and 301 participate in Raf regulation. FEBS Lett 579: 464-468, 2005.

103. Balan V, Leicht DT, Zhu J, Balan K, Kaplun A, Singh-Gupta V, Qin J, Ruan H, Comb MJ and Tzivion G: Identification of novel in vivo Raf-1 phosphorylation sites mediating positive feedback Raf-1 regulation by extracellular signal-regulated kinase. Mol Biol Cell 17: 1141-1153, 2006.

104. Brummer T, Naegele H, Reth M and Misawa Y: Identification of novel ERK-mediated feedback phosphorylation sites at the C-terminus of B-Raf. Oncogene 22: 8823-8834, 2003.

105. Ritt DA, Monson DM, Specht SI and Morrison DK: Impact of feedback phosphorylation and Raf heterodimerization on normal and mutant B-Raf signaling. Mol Cell Biol 30: 806-819, 2010.

106. Eblen ST, Slack-Davis JK, Tarcsafalvi A, Parsons JT, Weber MJ and Catling AD: Mitogen-activated protein kinase feedback phosphorylation regulates MEK1 complex formation and activation during cellular adhesion. Mol Cell Biol 24: 2308-2317, 2004

107. Rossomando AJ, Dent P, Sturgill TW and Marshak DR: Mitogen-activated protein kinase kinase 1 (MKK1) is negatively regulated by threonine phosphorylation. Mol Cell Biol 14 1594-1602, 1994.

108. Canal F, Palygin O, Pankratov Y, Corrêa SA and Müller J: Compartmentalization of the MAPK scaffold protein KSR1 modulates synaptic plasticity in hippocampal neurons. FASEB J 25: 2362-2372, 2011.

109. McKay MM, Ritt DA and Morrison DK: Signaling dynamics of the KSR1 scaffold complex. Proc Natl Acad Sci USA 106 11022-11027, 2009

110. Fey D, Croucher DR, Kolch W and Kholodenko BN: Crosstalk and signaling switches in mitogen-activated protein kinase cascades. Front Physiol 3: 355, 2012.

111. Caunt CJ, Finch AR, Sedgley KR and McArdle CA: Seven-transmembrane receptor signalling and ERK compartmentalization. Trends Endocrinol Metab 17: 276-283, 2006.

112. Owens DM and Keyse SM: Differential regulation of MAP kinase signalling by dual-specificity protein phosphatases. Oncogene 26: 3203-3213, 2007.

113. Huang CY and Tan TH: DUSPs, to MAP kinases and beyond. Cell Biosci 2: 24, 2012.

114. Peti W and Page R: Molecular basis of MAP kinase regulation. Protein Sci 22: 1698-1710, 2013.

115. Tanzola MB and Kersh GJ: The dual specificity phosphatase transcriptome of the murine thymus. Mol Immunol 43: 754-762, 2006

116. Hanafusa H, Torii S, Yasunaga T and Nishida E: Sprouty1 and Sprouty 2 provide a control mechanism for the Ras/MAPK signalling pathway. Nat Cell Biol 4: 850-858, 2002.

117. LitoP,Pratilas CA,JosephEW,Tadi M,Halilovic E,ZubrowskiM, Huang A, Wong WL, Callahan MK, Merghoub T, et al: Relief of profound feedback inhibition of mitogenic signaling by RAF inhibitors attenuates their activity in BRAFV600E melanomas. Cancer Cell 22: 668-682, 2012.

118. Lito P, Rosen N and Solit DB: Tumor adaptation and resistance to RAF inhibitors. Nat Med 19: 1401-1409, 2013.

119. Yusoff P, Lao DH, Ong SH, Wong ES, Lim J, Lo TL, Leong HF, Fong CW and Guy GR: Sprouty 2 inhibits the Ras/MAP kinase pathway by inhibiting the activation of Raf. J Biol Chem 277 3195-3201, 2002.

120. Dent P: Crosstalk between ERK, AKT, and cell survival. Cancer Biol Ther 15: 245-246, 2014

121. Mace PD, Wallez Y, Egger MF, Dobaczewska MK, Robinson H, Pasquale EB and Riedl SJ: Structure of ERK2 bound to PEA-15 reveals a mechanism for rapid release of activated MAPK. Nat Commun 4: 1681, 2013

122. Sinha D, Bannergee S, Schwartz JH, Lieberthal W and Levine JS: Inhibition of ligand-independent ERK $1 / 2$ activity in kidney proximal tubular cells deprived of soluble survival factors up-regulates Akt and prevents apoptosis. J Biol Chem 279: 10962-10972, 2004

123. Trencia A, Perfetti A, Cassese A, Vigliotta G, Miele C, Oriente F, Santopietro S, Giacco F, Condorelli G, Formisano P and Beguinot F: Protein kinase B/Akt binds and phosphorylates PED/PEA-15, stabilizing its antiapoptotic action. Mol Cell Biol 23: 4511-4521, 2003 
124. Aksamitiene E, Kiyatkin A and Kholodenko BN: Cross-talk between mitogenic Ras/MAPK and survival PI3K/Akt pathways: A fine balance. Biochem Soc Trans 40: 139-146, 2012

125. Ussar S and Voss T: MEK1 and MEK2, different regulators of the G1/S transition. J Biol Chem 279: 43861-43869, 2004.

126.Lee SJ, Lee SH, Yoon MH and Park BJ: A new p53 target gene, RKIP, is essential for DNA damage-induced cellular senescence and suppression of ERK activation. Neoplasia 15: 727-737, 2013

127. Li M, Zhou JY, Ge Y, Matherly LH and Wu GS: The phosphatase MKP1 is a transcriptional target of p53 involved in cell cycle regulation. J Biol Chem 278: 41059-41068, 2003.

128. Shen WH, Wang J, Wu J, Zhurkin VB and Yin Y: Mitogen-activated protein kinase phosphatase 2: A novel transcription target of p53 in apoptosis. Cancer Res 66: 6033-6039, 2006.

129. Ueda K, Arakawa H and Nakamura Y: Dual-specificity phosphatase 5 (DUSP5) as a direct transcriptional target of tumor suppressor p53. Oncogene 22: 5586-5591, 2003.

130. El Hasasna H, Athamneh K, Al Samri H, Karuvantevida N, Al Dhaheri Y, Hisaindee S, Ramadan G, Al Tamimi N, AbuQamar S, Eid A and Iratni R: Rhus coriaria induces senescence and autophagic cell death in breast cancer cells through a mechanism involving p38 and ERK1/2 activation. Sci Rep 5: 13013,2015

131. Wajapeyee N, Serra RW, Zhu X, Mahalingam M and Green MR: Oncogenic BRAF induces senescence and apoptosis through pathways mediated by the secreted protein IGFBP7. Cell 132: 363-374, 2008.

132. Ichimura A, Ruike Y, Terasawa K, Shimizu K and Tsujimoto G: MicroRNA-34a inhibits cell proliferation by repressing mitogen-activated protein kinase kinase 1 during megakaryocytic differentiation of K562 cells. Mol Pharmacol 77 : 1016-1024, 2010.
133. Sayed D, Rane S, Lypowy J, He M, Chen IY, Vashistha H, Yan L, Malhotra A, Vatner D and Abdellatif M: MicroRNA-21 targets Sprouty2 and promotes cellular outgrowths. Mol Biol Cell 19: 3272-3282, 2008

134. Deschênes-Simard X, Kottakis F, Lessard F, Saint-Germain E, Bourdeau VBardeesy N and Ferbeyre G: Tumor suppressor activity of the ERK/MAPK signaling: Inhibition of cell reprogramming by degradation of specific proteins. Cancer Res 74: 3895, 2014.

135. Plotnikov A,Flores K,Maik-Rachline G,Zehorai E, Kapri-Pardes E, Berti DA, Hanoch T, Besser MJ and Seger R: The nuclear translocation of ERK1/2 as an anticancer target. Nat Commun 6: 6685, 2015.

136. Schevzov G, Kee AJ, Wang B, Sequeira VB, Hook J, Coombes JD, Lucas CA, Stehn JR, Musgrove EA, Cretu A, et al: Regulation of cell proliferation by ERK and signal-dependent nuclear translocation of ERK is dependent on Tm5NM1-containing actin filaments. Mol Biol Cell 26: 2475-2490, 2015.

137. Wainstein E and Seger R: The dynamic subcellular localization of ERK: Mechanisms of translocation and role in various organelles. Curr Opin Cell Biol 39: 15-20, 2016.

138. Callejas-Valera JL, Guinea-Viniegra J, Ramirez-Castillejo C, Recio JA, Galan-Moya E, Martinez N, Rojas JM, Ramón y Cajal S and Sánchez-Prieto R: Ela gene expression blocks the ERK1/2 signaling pathway by promoting nuclear localization and MKP up-regulation: Implication in $\mathrm{v}-\mathrm{H}$-Ras-induced senescence. J Biol Chem 283: 13450-13458, 2008.

139. Gaumont-Leclerc MF, Mukhopadhyay UK, Goumard S and Ferbeyre G: PEA-15 is inhibited by adenovirus E1A and plays a role in ERK nuclear export and Ras-induced senescence. J Biol Chem 279: 46802-46809, 2004.

This work is licensed under a Creative Commons Attribution-NonCommercial-NoDerivatives 4.0 International (CC BY-NC-ND 4.0) License. 